\title{
Effect of Wastewaters on Heavy Metals Concentration in Different Soils of North Karnataka, India
}

\author{
Hanamantarao Jogan* and G.S. Dasog \\ Department of Soil Science and Agricultural Chemistry, UAS, Dharwad - 580 005, India \\ *Corresponding author
}

\begin{abstract}
A B S T R A C T
Keywords

Wastewater, Water quality, Lateritic soil, Red soil, Black Soil, Heavy metals, Lead, Cadmium, Chromium and Mercury

Article Info

Accepted:

10 March 2019

Available Online:

10 April 2019

Water scarcity and increase wastewater generation are twin problem associated which needs to be addressed to derive benefit for agricultural production. In this context laboratory study was conducted to characterize the wastewater from four different sources (Ugar sugar-Ugar khurd, West coast paper mill-Dandeli, Nectar beverages-Dharwad, Domestic sewage water-UAS campus Dharwad) in north Karnataka and were compared with freshwater. Spentwash from the Ugar Sugar Works distillery was singularly different from rest of the wastewaters and was characterized by its high pH, EC, TSS, TDS, BOD, COD, total nitrogen, phosphate, potassium and sulphate concentration. The effect of the wastewaters on the dominant soils of north Karnataka (Red, Lateritic and Black soil) were evaluated in column study during March-2014 to April-2015. Wide variation in water characteristics was recorded with wastewaters studied. The concentration of heavy metals increased in soils from 4 to 8 pore volumes application of various wastewaters. The highest lead concentration was observed in $\mathrm{W}_{4}$. The effect of different wastewaters in enhancing the lead concentration was highest in the black soil followed by red and then by lateritic soil. The concentration of chromium in spentwash treated soils at both 4 and 8 pore volumes passage was not only highest but singularly different from the rest.
\end{abstract}

\section{Introduction}

Increasing scarcity of water has turned to be regular phenomenon in the recent past. Priorities of the water use have also being changing with increased demand from the other sectors creating competition for the water use in agriculture sector. Rapid population increase in urban areas and industrialization gives rise to concern about appropriate water management practices.
Surface waters are being polluted by means of wastes or effluent discharge from the industries, domestic sewage, and municipal wastes etc. Further land application of wastewater is now becoming one of the most economically and ecologically viable method of disposal of these waters. With rapid expansion of cities and domestic water supply, quantity of grey/wastewater is increasing in the same proportion. Overall analysis of water resources indicates that in 
coming years, there will be a twin edged problem to deal with reduced fresh water availability and increased wastewater generation. Non-conventional water resources play greater role for water augmentation to achieve food security in water-scarce countries in the near future. Urban agriculture using wastewater provides food, income and employment to thousands of people. Nevertheless, reusing wastewater in agriculture is considered a deleterious practice since it may introduce pollutants to the environment, spread waterborne diseases, chemical contamination, soil salinization and contamination of groundwater sources, generate odour problems and result in aversion to the crops (IWMI, 2006). Contrarily, this kind of reuse may result in some benefits for soils, crops and farmers. Nowadays, the reuse of wastewater in agriculture is seen in some countries as a convenient environmental strategy. Globally around 3 to 3.5 million hectares are irrigated with raw and diluted wastewater irrigation. Wastewater is therefore, considered an appropriate option for reuse. Wastewater contains a significant load of biodegradable organic material and nutrients which are necessary for the growth of crops. Accumulation of organic matter in soil by irrigation with wastewater can be beneficial as it may result in the enhancement of physical structure of the soil, the increase in soil microbial activity and improvement of soil performance as a filter and degrading media for pollutants. The consistent use of wastewater in irrigation may stabilize the content of nutrients in the soil, even when growing crops with high nutritional requirements; this is because the continuous withdrawal of nutrients by plants is compensated by the constant input of organic and mineral components into the soil via wastewater. Effect of sewage wastewater on black soil (Varkey et al., 2015), paper mill wastewater on red soil (Sharma et al., 2014) and spentwash on black soil (Singh and Swami, 2014) have been studied. Composite study on characterization of the wastewater and their effect of different wastewaters on a wide range of soil is sparse. Information on effect of wastewater on a wide range of dominant soils of north Karnataka under controlled laboratory condition would give an insight into their capacity to bear the load of different chemical constituents. Thus a comprehensive study on the effect of different wastewaters characterized by different properties on different soil types was planned and executed under laboratory conditions.

\section{Materials and Methods}

The investigation was carried out by using three dominant soils of north Karnataka viz., Red (Ustropepts), Lateritic (Kanhaplic Haplustalfs), and Black soils (Typic Haplusterts). Four different water sources employed were domestic sewage, paper mill wastewater, soft drink factory wastewater, distillery spentwash and compared with fresh water (borewell water). The wastewater samples were collected from different sources were used for the column study. For the column study $5 \mathrm{~cm}$ diameter PVC pipes of 60 $\mathrm{cm}$ long with perforated bottom end caps were used. Initially the $\mathrm{BD}$ of each soil sample was measured, based on the BD and pipe column parameters (length and diameter) the quantity of soil filled in the each soil column was calculated.

Volume of pipe column $=\pi \mathrm{r}^{2} \mathrm{~h}, \mathrm{r}=2.5 \mathrm{~cm}$, $\mathrm{h}=60 \mathrm{~cm}$,

Volume of pipe column $=1178.25 \mathrm{~cm}^{3}$,

Weight of soil in column $=$ Volume $\times$ BD

Each soil samples were properly processed and passed through $2 \mathrm{~mm}$ sieve, before filling the columns. Amount water added in each column was based on maximum water holding capacity of different soils. Irrigation 
was given in terms of pore volumes, totally 8 pore volumes were passed through soil columns at an interval of 10 days. After passing two pore volumes one set of column was horizontally sectioned at an interval of 15 $\mathrm{cm}$.

\begin{tabular}{|l|c|c|c|c|}
\hline Soils & BD $\left(\mathbf{g ~ c m}^{-3}\right)$ & $\begin{array}{c}\text { Quantity of soil } \\
\text { added }(\mathbf{k g})\end{array}$ & MWHC (\%) & $\begin{array}{c}\text { Amount of water added } \\
\text { per one pore volume (ml) }\end{array}$ \\
\hline Red & 1.45 & 1.71 & 48.5 & 828 \\
\hline Lateritic & 1.52 & 1.80 & 50.5 & 903 \\
\hline Black & 1.34 & 1.57 & 67 & 1057 \\
\hline
\end{tabular}

Experiment was conducted using two factorial CRD with three replication. Factor I included different wastewater sources (1. Domestic sewage water- UAS Dharwad, 2. Soft drink factory treated wastewater- Nectar beverages, Dharwad, 3. Paper mill treated wastewaterWest Coast Paper mill Dandeli, 4. Distillery biomethanated spentwash (diluted with normal water in the ratio of 1:3) - Ugar sugar works Ugar khurd and 5. Normal water- Fresh borewell water UAS Dharwad) and factor II comprised of different soil depths $(0-15 \mathrm{~cm}$, $15-30 \mathrm{~cm}, 30-45 \mathrm{~cm}$ and $45-60 \mathrm{~cm})$.

The $\mathrm{pH}$ and EC of the waters were analyzed immediately after bringing the samples using $\mathrm{pH}$ meter and Systronics direct digital conductivity meter-304, respectively as described by Tandon, 1998. The dissolved solids in the effluents were determined by gravimetric method. The suspended solids in the effluents were determined by filtration method (Tandon, 1998). The Biological oxygen demand (BOD) of effluents were determined by measuring the dissolved oxygen of the samples before and after incubation at $20^{\circ} \mathrm{C}$ for five days by titrating it against sodium thiosulphate using starch indicator and the BOD of sewage water was calculated as described by Tandon (1998). The Chemical oxygen demand (COD) of wastewater was determined by open reflux method. The total nitrogen in water samples was determined titrimetrically after distilling the $\mathrm{NH}_{3}$ in boric acid mixed indicator. The phosphates in the effluents were determined by chloro-stannous reduced blue colour method. Potassium in the effluents was determined by using the flame photometer with suitable dilutions as described by Tandon (1998).

The $\mathrm{pH}$ of soil was determined in 1: 2.5 soils to water suspension after stirring the samples intermittently for half an hour using a Systronics direct digital $331 \mathrm{pH}$ meter. Electrical conductivity of the soil was determined in the supernatant of 1:2.5 soils to water suspension by using Systronics direct digital conductivity meter-304 (Sparks et al., 1996). The organic carbon content was determined by taking finely ground sample by wet oxidation method as described by Jackson (1967). Available nitrogen was estimated by modified alkaline potassium permanganate method (Sahrawat and Burford, 1982). Available phosphorus was determined by Olsen's method extracting phosphorus with $0.5 \mathrm{M} \mathrm{NaHCO}_{3} \mathrm{pH}$ 8.5. Available potassium was extracted with neutral normal ammonium acetate and the potassium in the solution was estimated by flame photometer (Jackson, 1967). Available sulphur was determined by Turbidometric method described by Sparks et al., (1996). The heavy metals like $\mathrm{Pb}, \mathrm{Hg}, \mathrm{Cd}$, and $\mathrm{Cr}$ in the soil samples were determined by using ICP-OES after adopting microwave digestion procedure (Shirisha et al., 2014). The experimental data was statistically analyzed as per Gomez and Gomez (1984) for soil physical and chemical properties. The computed data was interpreted with a critical 
differences level at 1 per cent.

\section{Results and Discussion}

The $\mathrm{pH}$ of sewage water and the wastewater from paper mill were near neutral whereas those from soft drink factory and distillery biomethanated spentwash were alkaline (Table 1). The EC of paper mill and soft drink factory wastewaters were around $2 \mathrm{dS} \mathrm{m} \mathrm{m}^{-1}$ whereas the sewage water was $1.23 \mathrm{dS} \mathrm{m}^{-1}$ closely followed by the normal water of the campus. The spentwash from the Ugar Sugar Works distillery was the most saline with an EC of $11.54 \mathrm{dS} \mathrm{m}^{-1}$ and in many other properties such as TDS, TSS, BOD, COD, Total $\mathrm{N}, \mathrm{P}$ and $\mathrm{K}$ contents was singularly different from rest of the wastewaters (Table 2). With respect to total $\mathrm{N}, \mathrm{P}$ and $\mathrm{K}$, the remaining three wastewaters had similar content. The sewage water was characterized by its high TSS, TDS, BOD and COD, the values of which were much less in soft drink factory wastewater and paper mill wastewater except for high TDS and COD (Table 2).

\section{Effect of different wastewaters on heavy metals concentration}

The heavy metal load in the soil columns were analyzed after passing 4 and 8 pore volumes of different wastewaters. The concentration of heavy metals increased in the soils from 4 to 8 pore volumes application of various wastewaters. highest lead concentration was observed in $\mathrm{W}_{4}(1.64 \mathrm{mg}$ $\mathrm{kg}^{-1}$ ) after 8 pore volumes application in red soil followed by $\mathrm{W}_{1}\left(1.27 \mathrm{mg} \mathrm{kg}^{-1}\right)$ with least in $\mathrm{W}_{5}\left(0.39 \mathrm{mg} \mathrm{kg}^{-1}\right)$. Similar trend was observed in other soils also with a general sequence $\mathrm{W}_{4}>\mathrm{W}_{1}>\mathrm{W}_{2}>\mathrm{W}_{3}>\mathrm{W}_{5}$ at both 4 and 8 pore volumes passage. However, the difference between $\mathrm{W}_{3}$ and $\mathrm{W}_{2}$ and between $\mathrm{W}_{2}$ and $\mathrm{W}_{1}$ or sometimes among the three was not significant in lateritic and black soils. The effect of different wastewaters in enhancing the lead concentration was highest in the black soil followed by red soil followed by lateritic soil (Table 3 and 4).

The concentration of chromium in spentwash treated soils at both 4 and 8 pore volumes passage was not only highest but singularly different from the rest. The effect of other three wastewaters was nearly same. The general sequence observed was $\mathrm{W}_{4}>\mathrm{W}_{2}>\mathrm{W}_{1}=\mathrm{W}_{3}>\mathrm{W}_{5}$ in all the soils. The effect of spentwash was highest in red and non-calcareous black soils and much less in lateritic and calcareous black soils. The concentration of chromium increased in $\mathrm{D}_{4}$ compared to $\mathrm{D}_{1}$ in all the soils (Table 3 and 4).

The effect of different wastewaters did not bring any change in the cadmium and mercury concentration in any of the soils at any of the pore volumes at any depth. Their concentration was same as that of soil treated with normal water.

The study revealed that continuous irrigation with different wastewaters has not resulted in buildup of heavy metals in soils. $\mathrm{Pb}$ and $\mathrm{Cr}$ content were highest in spentwash treated soils than others due to their high content in spentwash. Sewage water and soft drink factory wastewater were next in order in enhancing lead content in soils. Despite high $\mathrm{Pb}$ content in spentwash, its effect in enhancing $\mathrm{Pb}$ content was not appreciable, especially in lateritic and black soils. This may be related to adsorption of $\mathrm{Pb}$ by minerals present in lateritic soils (Das and Mondal, 2011) and by $\mathrm{CaCO}_{3}$ present in the black soils. In the case of $\mathrm{Cr}$, soft drink factory wastewater, sewage water and paper mill wastewater were in the order of abundance of $\mathrm{Cr}$ in soils which is directly related to its content in respective wastewaters. The effect of different wastewaters was appreciable in red and non- 
calcareous black soils but less in lateritic and calcareous black soils. This may be related to the interaction of wastewaters with iron and aluminum oxides in the former and $\mathrm{CaCO}_{3}$ in the latter.

Malla and Totawat (2007) reported that application of sewage water resulted in accumulation of heavy metals in soils. Vinod Kumar and Chopra (2011) also reported that higher accumulation of heavy metals in paper mill irrigated soils. But the concentration of heavy metals $(\mathrm{Pb}$ and $\mathrm{Cr})$ in the wastewater irrigated soils was below the maximum permissible limits as given by Kabata and Pendias (1992) and Department of Environment (1989).

Mercury and cadmium was not detected level in all the soils under different treatments. There was no significant difference found with respect to cadmium concentration within the treatments in soils. This is due to the fact that both these elements were not detected in the wastewaters used for the study (Table 5 and 6).

Table.1 Initial properties of soils studied

\begin{tabular}{|c|c|c|c|}
\hline Properties & Red soil & Lateritic soil & Black soil \\
\hline pH (1:2.5) & 6.15 & 5.60 & 7.10 \\
\hline $\mathrm{EC}\left(\mathrm{dS} \mathrm{m^{-1 } )}\right.$ & 0.14 & 0.28 & 0.21 \\
\hline $\mathrm{OC}\left(\mathrm{g} \mathrm{kg}^{-1}\right)$ & 8.0 & 4.6 & 4.7 \\
\hline Available- Nitrogen $\left(\mathrm{kg} \mathrm{ha}^{-1}\right)$ & 125.4 & 107 & 213 \\
\hline Available-Phosphorus $\left(\mathrm{kg} \mathrm{ha}^{-1}\right)$ & 32.5 & 14.0 & 20.5 \\
\hline Available- Potassium (kg ha $\left.{ }^{-1}\right)$ & 485 & 246 & 457 \\
\hline Available- Sulphur $\left(\mathrm{kg} \mathrm{ha}^{-1}\right)$ & 43.5 & 35.0 & 42.0 \\
\hline
\end{tabular}

Table.2 Chemical composition of water samples

\begin{tabular}{|c|c|c|c|c|c|}
\hline Parameters & Sewage & $\begin{array}{c}\text { Soft drink } \\
\text { factory }\end{array}$ & Paper mill & Spentwash & $\begin{array}{c}\text { Normal } \\
\text { water }\end{array}$ \\
\hline pH & 7.33 & 8.14 & 7.4 & 8.3 & 6.91 \\
\hline $\mathrm{EC}(\mathrm{dS} / \mathrm{m})$ & 1.23 & 2.09 & 1.85 & 11.54 & 0.72 \\
\hline TSS $\left(\mathrm{mg} \mathrm{L}^{-1}\right)$ & 480 & 18 & 36 & 1115 & 8 \\
\hline TDS $\left(\mathrm{mg} \mathrm{L}^{-1}\right)$ & 662 & 30 & 748 & 1975 & 12 \\
\hline BOD $\left(\mathrm{mg} \mathrm{L}^{-1}\right)$ & 256 & 8.29 & 21 & 1800 & 9 \\
\hline $\operatorname{COD}\left(\mathrm{mg} \mathrm{L}^{-1}\right)$ & 410 & 27 & 158 & 4508 & 14 \\
\hline $\mathrm{Ca}+\mathrm{Mg}\left(\operatorname{meq} \mathrm{L}^{-1}\right)$ & 8.6 & 4.8 & 5.6 & 13 & 4.0 \\
\hline Sodium (meq $\left.\mathbf{L}^{-1}\right)$ & 6.30 & 6.86 & 7.08 & 8.69 & 3.26 \\
\hline Total-N (mg L $\left.{ }^{-1}\right)$ & 23.7 & 20.57 & 25.4 & 130.4 & 1.25 \\
\hline Total-P $\left(\mathrm{mg} \mathrm{L}^{-1}\right)$ & 13.45 & 8.25 & 10.34 & 28 & 0.10 \\
\hline Total -K (meq $\left.\mathbf{L}^{-1}\right)$ & 0.74 & 0.72 & 1.35 & 39 & 0.20 \\
\hline $\mathrm{NO}_{3}-\mathrm{N}\left(\mathrm{mg} \mathrm{L}^{-1}\right)$ & 1.69 & 1.45 & 1.78 & 2.85 & 0.75 \\
\hline Sulphate (mg L $\left.\mathrm{L}^{-1}\right)$ & 7.22 & 7.87 & 8.13 & 9.25 & 2.5 \\
\hline
\end{tabular}


Table.3 $\mathrm{Pb}$ and $\mathrm{Cr}\left(\mathrm{mg} \mathrm{kg}^{-1}\right)$ concentrations in red and lateritic soils after passing 4 and 8 pore volumes of different wastewaters

\begin{tabular}{|c|c|c|c|c|c|c|c|c|c|c|c|c|}
\hline \multicolumn{13}{|c|}{ Red soil } \\
\hline \multirow[t]{2}{*}{ WS } & \multicolumn{3}{|c|}{4 pore volumes $(\mathrm{Pb})$} & \multicolumn{3}{|c|}{8 pore volumes $(\mathrm{Pb})$} & \multicolumn{3}{|c|}{4 pore volumes $(\mathrm{Cr})$} & \multicolumn{3}{|c|}{8 pore volumes $(\mathrm{Cr})$} \\
\hline & D1 & D4 & Mean & D1 & D4 & Mean & D1 & D4 & Mean & D1 & D4 & Mean \\
\hline W1 & 1.07 & 1.26 & 1.16 & 1.17 & 1.37 & 1.27 & 0.07 & 0.10 & 0.09 & 0.09 & 0.12 & 0.11 \\
\hline W2 & 0.87 & 1.08 & 0.98 & 0.98 & 1.35 & 1.17 & 0.07 & 0.17 & 0.12 & 0.10 & 0.17 & 0.14 \\
\hline W3 & 0.75 & 1.07 & 0.91 & 0.83 & 1.25 & 1.04 & 0.05 & 0.10 & 0.08 & 0.08 & 0.11 & 0.10 \\
\hline W4 & 1.17 & 1.92 & 1.54 & 1.21 & 2.07 & 1.64 & 0.17 & 0.34 & 0.26 & 0.25 & 0.38 & 0.32 \\
\hline W5 & 0.32 & 0.45 & 0.39 & 0.32 & 0.45 & 0.39 & 0.01 & 0.03 & 0.02 & 0.01 & 0.03 & 0.02 \\
\hline Mean & 0.84 & 1.16 & 1.00 & 0.90 & 1.30 & 1.10 & 0.07 & 0.15 & 0.11 & 0.11 & 0.16 & 0.13 \\
\hline \multirow[t]{2}{*}{ W } & S.Em \pm & \multicolumn{2}{|c|}{ CD at $1 \%$} & S.Em \pm & \multicolumn{2}{|c|}{ CD at $1 \%$} & S.Em \pm & \multicolumn{2}{|c|}{ CD at $1 \%$} & S.Em \pm & \multicolumn{2}{|c|}{ CD at $1 \%$} \\
\hline & 0.013 & \multicolumn{2}{|c|}{0.05} & 0.016 & \multicolumn{2}{|c|}{0.06} & 0.008 & \multicolumn{2}{|c|}{0.03} & 0.002 & \multicolumn{2}{|c|}{0.01} \\
\hline D & 0.012 & \multicolumn{2}{|c|}{0.05} & 0.014 & \multicolumn{2}{|c|}{0.05} & 0.007 & \multicolumn{2}{|c|}{0.03} & 0.001 & \multicolumn{2}{|c|}{0.01} \\
\hline $\begin{array}{c}\text { Wx } \\
\text { D }\end{array}$ & 0.027 & \multicolumn{2}{|c|}{0.10} & 0.031 & \multicolumn{2}{|c|}{0.12} & 0.016 & \multicolumn{2}{|c|}{0.06} & 0.003 & \multicolumn{2}{|c|}{0.01} \\
\hline \multicolumn{13}{|c|}{ Lateritic soil } \\
\hline W1 & 0.83 & 1.10 & 0.97 & 0.88 & 1.18 & 1.03 & 0.02 & 0.03 & 0.03 & 0.05 & 0.09 & 0.07 \\
\hline W2 & 0.88 & 1.15 & 1.02 & 0.80 & 1.22 & 1.01 & 0.03 & 0.05 & 0.04 & 0.06 & 0.10 & 0.08 \\
\hline W3 & 0.82 & 1.07 & 0.95 & 0.87 & 1.13 & 1.00 & 0.02 & 0.03 & 0.03 & 0.04 & 0.07 & 0.06 \\
\hline W4 & 0.96 & 1.20 & 1.08 & 1.07 & 1.48 & 1.27 & 0.04 & 0.10 & 0.07 & 0.07 & 0.15 & 0.11 \\
\hline W5 & 0.27 & 0.34 & 0.30 & 0.27 & 0.34 & 0.30 & 0.02 & 0.02 & 0.02 & 0.02 & 0.02 & 0.02 \\
\hline Mean & 0.75 & 0.97 & 0.86 & 0.78 & 1.07 & 0.92 & 0.03 & 0.05 & 0.04 & 0.05 & 0.09 & 0.07 \\
\hline W & S.Em \pm & \multicolumn{2}{|c|}{ CD at $1 \%$} & S.Em \pm & \multicolumn{2}{|c|}{ CD at $1 \%$} & S.Em \pm & \multicolumn{2}{|c|}{ CD at $1 \%$} & S.Em \pm & \multicolumn{2}{|c|}{ CD at $1 \%$} \\
\hline & 0.017 & \multicolumn{2}{|c|}{0.07} & 0.018 & \multicolumn{2}{|c|}{0.07} & 0.001 & & & 0.001 & & \\
\hline D & 0.016 & & & 0.016 & & & 0.001 & & & 0.001 & & \\
\hline $\begin{array}{c}\text { Wx } \\
\text { D }\end{array}$ & 0.035 & & & 0.036 & & & 0.003 & & & 0.003 & & \\
\hline $\begin{array}{l}\text { W1- Sev } \\
\text { W5- nor } \\
\text { D4= 45 } \\
\text { (each va }\end{array}$ & $\begin{array}{l}\text { ge water; } \\
\text { hal tap wat } \\
060 \mathrm{~cm} \text { de } \\
\text { les mean o }\end{array}$ & $\begin{array}{c}\text { W2- } \\
\text { D1= } \\
\text { M - I } \\
\text { plicates }\end{array}$ & $\begin{array}{l}\text { drink fac } \\
15 \mathrm{~cm} \mathrm{de}\end{array}$ & y wastewa & & $\begin{array}{l}3 \text { - paper } n \\
=15 \text { to } 3\end{array}$ & $\begin{array}{l}\text { wastewat } \\
\text { m depth; }\end{array}$ & & $\begin{array}{l}\text { listillery } \\
30 \text { to } 45\end{array}$ & $\begin{array}{l}\text { twash } \\
\text { depth }\end{array}$ & & \\
\hline
\end{tabular}


Table.4 $\mathrm{Pb}$ and $\mathrm{Cr}\left(\mathrm{mg} \mathrm{kg}^{-1}\right)$ concentrations in black soil after passing 4 and 8 pore volumes of different wastewaters

\begin{tabular}{|l|c|c|c|c|c|c|c|c|c|c|c|}
\hline \multicolumn{10}{|c|}{ Calcareous soil } \\
\hline
\end{tabular}


Table.5 Cd and $\mathrm{Hg}\left(\mathrm{mg} \mathrm{kg}^{-1}\right)$ concentrations in red and lateritic soils after passing 4 and 8 pore volumes of different wastewaters

\begin{tabular}{|c|c|c|c|c|c|c|c|c|c|c|c|c|}
\hline \multicolumn{13}{|c|}{ Red soil } \\
\hline \multirow[t]{2}{*}{ WS } & \multicolumn{3}{|c|}{4 pore volumes $(\mathrm{Cd})$} & \multicolumn{3}{|c|}{8 pore volumes $(\mathrm{Cd})$} & \multicolumn{3}{|c|}{4 pore volumes $(\mathrm{Hg})$} & \multicolumn{3}{|c|}{8 pore volumes $(\mathrm{Hg})$} \\
\hline & D1 & D4 & Mean & D1 & D4 & Mean & D1 & D4 & Mean & D1 & D4 & Mean \\
\hline W1 & 0.03 & 0.03 & 0.03 & 0.03 & 0.03 & 0.03 & BDL & BDL & $\mathrm{BDL}$ & BDL & BDL & $\mathrm{BDL}$ \\
\hline W2 & 0.03 & 0.03 & 0.03 & 0.03 & 0.03 & 0.03 & BDL & BDL & BDL & BDL & BDL & BDL \\
\hline W3 & 0.03 & 0.03 & 0.03 & 0.03 & 0.03 & 0.03 & BDL & BDL & BDL & BDL & $\mathrm{BDL}$ & BDL \\
\hline W4 & 0.03 & 0.03 & 0.03 & 0.03 & 0.03 & 0.03 & BDL & BDL & BDL & BDL & BDL & BDL \\
\hline W5 & 0.03 & 0.03 & 0.03 & 0.03 & 0.03 & 0.03 & BDL & BDL & BDL & BDL & $\mathrm{BDL}$ & BDL \\
\hline Mean & $\mathbf{0 . 0 3}$ & 0.03 & $\mathbf{0 . 0 3}$ & 0.03 & 0.03 & $\mathbf{0 . 0 3}$ & BDL & BDL & BDL & BDL & BDL & BDL \\
\hline \multirow[t]{2}{*}{ W } & S.Em \pm & \multicolumn{2}{|c|}{ CD at $1 \%$} & S.Em \pm & \multicolumn{2}{|c|}{ CD at $1 \%$} & S.Em \pm & \multicolumn{2}{|c|}{ CD at $1 \%$} & S.Em \pm & \multicolumn{2}{|c|}{ CD at $1 \%$} \\
\hline & 0.00 & \multicolumn{2}{|c|}{ NS } & 0.00 & \multicolumn{2}{|c|}{ NS } & 0.00 & \multicolumn{2}{|c|}{ NS } & 0.00 & \multicolumn{2}{|c|}{ NS } \\
\hline D & 0.00 & \multicolumn{2}{|c|}{ NS } & 0.00 & \multicolumn{2}{|c|}{ NS } & 0.00 & \multicolumn{2}{|c|}{ NS } & 0.00 & \multicolumn{2}{|c|}{ NS } \\
\hline $\begin{array}{c}\text { Wx } \\
\mathbf{D}\end{array}$ & 0.00 & \multicolumn{2}{|c|}{ NS } & 0.00 & \multicolumn{2}{|c|}{ NS } & 0.00 & \multicolumn{2}{|c|}{ NS } & 0.00 & \multicolumn{2}{|c|}{ NS } \\
\hline \multicolumn{13}{|c|}{ Lateritic soil } \\
\hline W1 & 0.02 & 0.02 & 0.02 & 0.02 & 0.02 & 0.02 & BDL & BDL & BDL & BDL & BDL & BDL \\
\hline W2 & 0.02 & 0.02 & 0.02 & 0.02 & 0.02 & 0.02 & BDL & BDL & BDL & BDL & $\mathrm{BDL}$ & BDL \\
\hline W3 & 0.02 & 0.02 & 0.02 & 0.02 & 0.02 & 0.02 & BDL & BDL & BDL & BDL & $\mathrm{BDL}$ & BDL \\
\hline W4 & 0.02 & 0.02 & 0.02 & 0.02 & 0.02 & 0.02 & BDL & BDL & BDL & BDL & BDL & BDL \\
\hline W5 & 0.02 & 0.02 & 0.02 & 0.02 & 0.02 & 0.02 & BDL & BDL & BDL & $\mathrm{BDL}$ & BDL & BDL \\
\hline Mean & 0.02 & 0.02 & 0.02 & 0.02 & 0.02 & 0.02 & BDL & BDL & BDL & BDL & BDL & BDL \\
\hline W & S.Em \pm & \multicolumn{2}{|c|}{ CD at $1 \%$} & S.Em \pm & \multicolumn{2}{|c|}{ CD at $1 \%$} & S.Em \pm & \multicolumn{2}{|c|}{ CD at $1 \%$} & S.Em \pm & \multicolumn{2}{|c|}{ CD at $1 \%$} \\
\hline & 0.00 & \multicolumn{2}{|c|}{ NS } & 0.00 & \multicolumn{2}{|c|}{ NS } & 0.00 & & & 0.00 & & \\
\hline D & 0.00 & & & 0.00 & & & 0.00 & & & 0.00 & & \\
\hline $\begin{array}{c}\text { Wx } \\
\text { D }\end{array}$ & 0.00 & & & 0.00 & & & 0.00 & & & 0.00 & & \\
\hline $\begin{array}{l}\text { W1- Se } \\
\text { D1 }=0 \mathrm{t} \\
\text { (each va }\end{array}$ & $\begin{array}{l}\text { age water } \\
15 \mathrm{~cm} \mathrm{dept}\end{array}$ & $\begin{array}{r}\text { W2- } \\
\text { D2 } \\
\text { icates }\end{array}$ & $\begin{array}{l}t \text { drink fac } \\
\text { to } 30 \mathrm{~cm}\end{array}$ & $\begin{array}{l}\text { y wastewa } \\
\text { pth }\end{array}$ & & $\begin{array}{l}\text { oaper mill } \\
3=30 \text { to } 4\end{array}$ & $\begin{array}{l}\text { astewater } \\
\text { m depth }\end{array}$ & & $\begin{array}{l}\text { listillery } \\
45 \text { to } 60 \mathrm{c}\end{array}$ & $\begin{array}{l}\text { ntwash } \\
\text { depth }\end{array}$ & $\begin{array}{c}\text { W5- nor } \\
\text { M }\end{array}$ & $\begin{array}{l}\text { tap water } \\
\text { ean }\end{array}$ \\
\hline
\end{tabular}


Table.6 $\mathrm{Cd}$ and $\mathrm{Hg}\left(\mathrm{mg} \mathrm{kg}^{-1}\right)$ concentrations in black soil after passing 4 and 8 pore volumes of different wastewaters

\begin{tabular}{|c|c|c|c|c|c|c|c|c|c|c|c|c|}
\hline \multicolumn{13}{|c|}{$\begin{array}{l}\text { Calcareous soil } \\
\end{array}$} \\
\hline \multirow[t]{2}{*}{ WS } & \multicolumn{3}{|c|}{4 pore volumes $(\mathrm{Cd})$} & \multicolumn{3}{|c|}{8 pore volumes $(\mathbf{C d})$} & \multicolumn{3}{|c|}{4 pore volumes $(\mathrm{Hg})$} & \multicolumn{3}{|c|}{8 pore volumes $(\mathrm{Hg})$} \\
\hline & D1 & D4 & Mean & D1 & D4 & Mean & D1 & D4 & Mean & D1 & D4 & Mean \\
\hline W1 & 0.02 & 0.02 & 0.02 & 0.02 & 0.02 & 0.02 & BDL & BDL & BDL & BDL & BDL & BDL \\
\hline W2 & 0.02 & 0.02 & 0.02 & 0.02 & 0.02 & 0.02 & BDL & BDL & BDL & BDL & BDL & BDL \\
\hline W3 & 0.02 & 0.02 & 0.02 & 0.02 & 0.02 & 0.02 & BDL & BDL & BDL & BDL & BDL & BDL \\
\hline W4 & 0.02 & 0.02 & 0.02 & 0.02 & 0.02 & 0.02 & BDL & BDL & BDL & BDL & BDL & BDL \\
\hline W5 & 0.02 & 0.02 & 0.02 & 0.02 & 0.02 & 0.02 & BDL & BDL & BDL & BDL & BDL & BDL \\
\hline Mean & 0.02 & 0.02 & 0.02 & 0.02 & 0.02 & 0.02 & BDL & BDL & BDL & BDL & BDL & BDL \\
\hline \multirow[t]{2}{*}{ W } & S.Em \pm & \multicolumn{2}{|c|}{ CD at $1 \%$} & S.Em \pm & \multicolumn{2}{|c|}{ CD at $1 \%$} & S.Em \pm & \multicolumn{2}{|c|}{ CD at $1 \%$} & S.Em \pm & \multicolumn{2}{|c|}{ CD at $1 \%$} \\
\hline & 0.00 & \multicolumn{2}{|c|}{ NS } & 0.00 & \multicolumn{2}{|c|}{ NS } & 0.00 & \multicolumn{2}{|c|}{ NS } & 0.00 & \multicolumn{2}{|c|}{ NS } \\
\hline D & 0.00 & \multicolumn{2}{|c|}{ NS } & 0.00 & \multicolumn{2}{|c|}{ NS } & 0.00 & \multicolumn{2}{|c|}{ NS } & 0.00 & \multicolumn{2}{|c|}{ NS } \\
\hline $\begin{array}{c}\text { Wx } \\
\mathbf{D}\end{array}$ & 0.00 & \multicolumn{2}{|c|}{ NS } & 0.00 & \multicolumn{2}{|c|}{ NS } & 0.00 & \multicolumn{2}{|c|}{ NS } & 0.00 & \multicolumn{2}{|c|}{ NS } \\
\hline \multicolumn{3}{|c|}{$\begin{array}{l}\text { W1- Sewage water } \\
\text { D1 }=0 \text { to } 15 \mathrm{~cm} \text { depth } \\
\text { values mean of triplicates) }\end{array}$} & $\begin{array}{l}\text { drink fac } \\
\text { to } 30 \mathrm{~cm}\end{array}$ & $\begin{array}{l}\text { y wastewa } \\
\text { th }\end{array}$ & \multicolumn{3}{|c|}{$\begin{array}{l}\text { W3- paper mill wastewater } \\
\text { D3 }=30 \text { to } 45 \mathrm{~cm} \text { depth }\end{array}$} & \multicolumn{3}{|c|}{$\begin{array}{l}\text { W4-distillery spentwash } \\
\text { D4= } 45 \text { to } 60 \mathrm{~cm} \text { depth }\end{array}$} & \multicolumn{2}{|c|}{$\begin{array}{l}\text { W5- normal tap water } \\
\text { M - Mean (each }\end{array}$} \\
\hline
\end{tabular}


In conclusion, the concentration of heavy metals increased in soils from 4 to 8 pore volumes application of various wastewaters. The highest lead concentration was observed in $\mathrm{W}_{4}$. The effect of different wastewaters in enhancing the lead concentration was highest in the two black soils followed by red and then by lateritic soil. The concentration of chromium in spentwash treated soils at both 4 and 8 pore volumes passage was not only highest but singularly different from the rest. The effect of other three wastewaters was nearly same. The effect of spentwash was highest in red and non-calcareous black soils and much less in lateritic and calcareous black soils. The concentration of lead and chromium was more in $\mathrm{D}_{4}$ compared to $\mathrm{D}_{1}$ in all the soils. Cadmium and mercury were not detected in any of the soils as none of the wastewaters contained them.

\section{References}

Das, B. and Mondal, NK. 2011. Calcareous soil as a new adsorbent to remove lead from aqueous solution: equilibrium, kinetic and thermodynamic study. Univ. J. Environ. Res. Tech., 1(4): 515-530.

Department of Environment, 1989. The use of sewage sludge in agriculture. A National Code of Practice, HSMO, London, UK.

Gomez, KA. and Gomez, AA. 1984. Statistical Procedures for Agricultural Research. John Willey and Sons, New York (USA).

IWMI, 2006. Recycling realities: Managing health risk to make wastewater use an asset. Water policy briefing, issue 17.

Jackson, ML. 1967. Soil Chemical Analysis. Prentice Hall of India Private Ltd, New Delhi.

Kabata, P. and Pendias, H. 1992. Trace Elements in Soils and Plants, CRC Press Inc. Boca
Raton, pp. 1-356, Florida, USA.

Malla, R. and Totawat, KL. 2007. Effect of municipal sewage on soil properties and chemical buildup of vegetable crops grown on Haplustepts of sub-humid southern plains of Rajasthan. J. Indian Soc. Soil Sci., 54(2): 226-231.

Sahrawat, KL. and Burford, JR. 1982. Modification in the alkaline permanganate method for assessing the availability of soil nitrogen in upland soils. Soil Sci., 133(1-6): 53-57.

Sharma, V., Umesh, KG. and Deepak Arora. 2014. Impact of pulp and paper mill effluent on physico-chemical properties of soil. Arch. Appl. Sci. Res., 6 (2): 12-17.

Shirisha, K., Sahrawat, KL. Prathibha Devi, B. and Wani, SP. 2014. Simple and accurate method for routine analysis of heavy metals in soil, plant and fertilizer. Communi. Soil Sci. Plant Analysis, 45:2201-2206.

Singh, SV. and Swami, VK. 2014. Impact of distillery wastewater irrigation on chemical properties of agriculture soil. Int. $J$. Innovative Res. Sci. Engg. Tech., 3 (10): 17028-17032.

Sparks, DL. Page, AL. Helmake, PA. Loppert RH. Soltanpour, PN. Tabatabai, MA. Johnston, CT. and Summer, ME. 1996. Methods of Soil Analysis, Part 3, pp. 610-624.

Tandon, HLS. 1998. Methods of Analysis of Soils, Plants, Water and Fertilizers. Fert. Dev. and consultation Org., New Delhi, India, pp. 916.

Varkey, BK. Dasog, GS. Wani, SP. Sahrawat, KL. Hebbara, M. and Patil, CR. 2015. Impact of long-term application of domestic sewage water on soil properties around Hubli city in Karnataka, India. Agril. Res., 4(3): 272-276.

Vinod Kumar and Chopra, AK. 2011. Alterations in physico-chemical characteristics of soil after irrigation with Paper mill effluent. $J$. Chem. Pharm. Res., 3(6):7-22.

\section{How to cite this article:}

Hanamantarao Jogan and Dasog, G.S. 2019. Effect of Wastewaters on Heavy Metals Concentration in Different Soils of North Karnataka, India. Int.J.Curr.Microbiol.App.Sci. 8(04): 1070-1079. doi: https://doi.org/10.20546/ijcmas.2019.804.124 